\title{
ANALYSIS OF THERMALLY-INDUCED TRANSFORMATIONS OF SILICA ROCKS AFTER HIGH TEMPERATURE HEAT TREATMENT
}

\author{
Jishi GENG ${ }^{1)}$, Qiang SUN ${ }^{1)}$ *, Yuchun ZHANG ${ }^{2)}$ and Yuliang ZHANG ${ }^{1)}$ \\ 1) School of Resources and Geosciences, China University of Mining and Technology, Xuzhou, Jiangsu Province 221116, P.R. China \\ ${ }^{2}$ State-Province Joint Engineering Laboratory in Spatial Information Technology for High-Speed Railway Safety, Southwest Jiaotong \\ University, Chengdu, Sichuan Province 610031, P. R. China \\ *Corresponding author's e-mail: sunqiang04@126.com
}

\begin{tabular}{l} 
ARTICLE INFO \\
\hline Article history: \\
Received 31 March 2017 \\
Accepted 12 July 2017 \\
Available online 22 August 2017 \\
\hline
\end{tabular}

Keywords:

High temperature

Silica rocks

Non-destructive analytical method

Thermal expansion

\begin{abstract}
High temperature alters the internal microstructure of rocks and consequently changes the physical and mechanical properties of rocks. Many studies have been carried out to examine the transformations in the microstructures of rocks under high temperature through near infrared spectroscopy (NIR), Raman spectroscopy, or thermo gravimetric analysis (TGA). The current review synthesizes the data from a number of literatures and summarizes the major transformations of silica rocks under high temperature. The analysis shows that silica rocks starts to lose the water adsorbed in open pores upon heating at about $150{ }^{\circ} \mathrm{C}$. At $200-300{ }^{\circ} \mathrm{C}$, the reaction between $\mathrm{SiOH}$ (silanole) in the rocks generates new $\mathrm{Si}-\mathrm{O}-\mathrm{Si}$ bonds as well as $\mathrm{H}_{2} \mathrm{O}$, and decreases the open pores. The rocks undergo volume expansion at $>550{ }^{\circ} \mathrm{C}$, and the volume contracts and forms new micro pores or cracks which play an important role in the evacuation of the water.
\end{abstract}

\section{INTRODUCTION}

The effect of high temperature on rock is of concern in many research areas, such as geology, civil engineering, mining, etc. (Fridleifsson, 2001; Kovačević et al., 2013; Hofmeister, 2014; Abdulagatov et al., 2015; Verma et al., 2016; Wang et al., 2016; Xiao et al., 2016). Many scholars have studied the crystal structure and composition of minerals by spectroscopy (Post and Noble, 1993). It is well recognized that thermal transformations can alter the mechanical properties of rocks (Tiffagom, 1998; Léa et al., 2005; Brown et al., 2009; Mourre et al., 2010). For lithic raw materials, most of the stone implements are made of flint, which is a chemically precipitated sedimentary silica rock consisting mostly of length-fast (LF) chalcedony. The LF-chalcedony is a cryptocrystalline $\alpha$-quartz $\left(\mathrm{SiO}_{2}\right)$ that is $50-100 \mathrm{~nm}$ in size (Ríos et al., 2001) and contains chemically bound hydroxyl groups in the form of silanole $(\mathrm{SiOH})$ and molecular water $\left(\mathrm{H}_{2} \mathrm{O}\right)$ (Flörke et al., 1982; Graetsch et al., 1985). This rock contains up to 0.7 wt $\%$ of $\mathrm{SiOH}$ and about the same amount of $\mathrm{H}_{2} \mathrm{O}$ in its structure (Schmidt et al., 2011). Silanole ( $\mathrm{SiOH})$ is related to the grain boundaries and the defect sites inside the quartz crystallites, and $\mathrm{H}_{2} \mathrm{O}$ is mainly found in the fluid inclusions and pores inside the rocks (Flörke et al., 1982). The silcrete rock undergoes a number of readily identifiable physical changes upon heating, including reddening (Schindler et al., 1982), loss of porosity (Schmidt et al., 2013b), occasional heat fracturing (Mercieca and Hiscock, 2008), and increased brittleness (Domanski and Webb, 1992). The major transformation of the silica rock is the hydroxylation of $\mathrm{SiOH}$, which starts at about $200-300{ }^{\circ} \mathrm{C}$ (Schmidt et al., 2012b). Expansion and contraction of the volume of rocks expedite the development of micro cracks. Besides, the transition from the $\alpha$ phase to the $\beta$ phase in quartz at about $573{ }^{\circ} \mathrm{C}$ facilitates the emission of water from rocks (Fu and $\mathrm{Xu}, 1992$; Höfer and Schilling, 2002). These chemical reactions are helpful for understanding the mechanical transformations of rocks and analyzing the variation of open pores (Schmidt et al., 2011; Schmidt et al., 2012b).

This paper collects from the published literatures the data on the content of $\mathrm{H}_{2} \mathrm{O}$ and $\mathrm{SiOH}$ in silica rocks, and then proceeds to analyze the evolution of silica rocks under high temperature.

\section{DATA AND METHODS}

\subsection{DATA COLLECTION}

Data were collected from a number of research articles. Table 1 lists the detailed information about the data collected for analysis, including sample number, rock type, literature source, water contents, sample descriptions, and main minerals or chemical 
Table 1 List of collected data ( $c$ : concentration before annealing).

\begin{tabular}{|c|c|c|c|c|c|}
\hline Sample & Ref. & Descriptions & $\begin{array}{l}\text { Thickness } \\
\text { (um) }\end{array}$ & $\begin{array}{c}c \\
(\mathrm{SiOH}) \\
\left(\mathrm{wt}^{0} \%\right)\end{array}$ & $\begin{array}{c}c \\
(\mathrm{H} 2 \mathrm{O}) \\
(\mathrm{wt} \%) \\
\end{array}$ \\
\hline $\begin{array}{l}\text { Hongheshui } \\
\text { flint }\end{array}$ & $\begin{array}{l}\mathrm{Fu} \text { and } \mathrm{Xu}, \\
(1992)\end{array}$ & $\begin{array}{c}\text { Light grey flint, entirely quartz, Hongheshui } \\
\text { Guangxi, China }\end{array}$ & - & - & - \\
\hline $\begin{array}{l}\text { Jiangnan } \\
\text { flint }\end{array}$ & $\begin{array}{l}\mathrm{Fu} \text { and } \mathrm{Xu}, \\
\text { (1992) }\end{array}$ & $\begin{array}{c}\text { Black flint, entirely quartz, Jiangnan Jiangsu, } \\
\text { China }\end{array}$ & - & - & - \\
\hline VC-12-01 & $\begin{array}{l}\text { Schmidt, et } \\
\text { al. }(2013 a)\end{array}$ & $\begin{array}{l}\text { Light-brown to yellowish homogeneous flint } \\
\text { with } 85 \% \text { LF-chalcedony, } 15 \% \text { LS- } \\
\text { chalcedony, minor macro-quartz, Barremian } \\
\text { to lower Abtian. }\end{array}$ & $1280 \pm 5$ & - & - \\
\hline VC-12-02 & $\begin{array}{l}\text { Schmidt et } \\
\text { al. (2013a) }\end{array}$ & & $1200 \pm 5$ & . & - \\
\hline SA-11-12A & $\begin{array}{l}\text { Schmidt et } \\
\text { al. }(2013 b)\end{array}$ & $\begin{array}{c}\text { Silcrete outcrops with trace Illite, Western } \\
\text { Cape region, South African. }\end{array}$ & $469 \pm 5$ & 0.19 & 0.18 \\
\hline SA-11-36 & $\begin{array}{l}\text { Schmidt et } \\
\text { al. }(2013 \mathrm{~b})\end{array}$ & $\begin{array}{l}\text { Silcrete outcrops with trace Microcline and } \\
\text { Illite, Western Cape region, South African. }\end{array}$ & $515 \pm 5$ & 0.86 & 1.48 \\
\hline PS-09-04 & $\begin{array}{l}\text { Schmidt et } \\
\text { al. }(2011)\end{array}$ & Coniacian black flint, Étretat, France. & $545 \pm 5$ & 0.58 & 0.73 \\
\hline PS-09-25 & $\begin{array}{l}\text { Schmidt et } \\
\text { al. }(2011)\end{array}$ & $\begin{array}{c}\text { Upper Cretaceous brown flint, Le grand } \\
\text { Pressigny, France. }\end{array}$ & $998 \pm 5$ & 0.72 & 0.74 \\
\hline PS-09-07 & $\begin{array}{l}\text { Schmidt et } \\
\text { al. }(2011)\end{array}$ & $\begin{array}{l}\text { Santonian grey flint from dedolomised chalk } \\
\text { level, cliffs of Étretat, France. }\end{array}$ & $1037 \pm 5$ & 0.45 & 0.45 \\
\hline PS-09-14 & $\begin{array}{l}\text { Schmidt et } \\
\text { al. }(2011)\end{array}$ & Turonian black flint, cliffs of Étretat, France. & $538 \pm 5$ & 0.5 & 0.71 \\
\hline PS-09-15 & $\begin{array}{l}\text { Schmidt et } \\
\text { al. }(2011)\end{array}$ & $\begin{array}{c}\text { Turonian brown flint, north of Le grand } \\
\text { Pressigny, France. }\end{array}$ & $982 \pm 5$ & 0.75 & 0.75 \\
\hline PS-09-11 & $\begin{array}{l}\text { Schmidt et } \\
\text { al. }(2011)\end{array}$ & Turonian black flint, cliffs of Étretat, France. & $997 \pm 5$ & 0.63 & 0.56 \\
\hline PS-09-13 & $\begin{array}{l}\text { Schmidt et } \\
\text { al. }(2011)\end{array}$ & $\begin{array}{c}\text { Turonian black flint with grey cortex, cliffs } \\
\text { of Étretat, France. }\end{array}$ & $556 \pm 5$ & 0.6 & 0.59 \\
\hline PS-09-38 & $\begin{array}{l}\text { Schmidt et } \\
\text { al. }(2011)\end{array}$ & $\begin{array}{l}\text { Upper Cretaceous light grey flint containing } \\
\text { lutécite. From detritic sand deposit, north of } \\
\text { Le grand Pressigny, France. }\end{array}$ & $1050 \pm 5$ & 0.6 & 0.73 \\
\hline PS-09-41 & $\begin{array}{l}\text { Schmidt et } \\
\text { al. }(2011)\end{array}$ & $\begin{array}{c}\text { Turonian brown to ochre flint, Le grand } \\
\text { Pressigny, France. }\end{array}$ & $549 \pm 5$ & 0.61 & 0.67 \\
\hline TR-S-01 & $\begin{array}{l}\text { Schmidt et } \\
\text { al. }(2012 b)\end{array}$ & $\begin{array}{c}\text { Turonian flint, entirely LF-chalcedony. } \\
\text { North of Tours, France. }\end{array}$ & 792 & 0.81 & 0.38 \\
\hline GP-S-01 & $\begin{array}{l}\text { Schmidt et } \\
\text { al. }(2012 b)\end{array}$ & $\begin{array}{l}\text { Reddish brown Turonian flint, entirely LF- } \\
\text { chalcedony. Le Grand Pressigny, France. }\end{array}$ & 779 & 0.38 & 0.28 \\
\hline SB-Cal-06 & $\begin{array}{l}\text { Schmidt et } \\
\text { al. }(2011)\end{array}$ & Length-fast chalcedony from an agate geode. & $720 \pm 10$ & 0.32 & 0.61 \\
\hline SB-Cal-07 & $\begin{array}{l}\text { Schmidt et } \\
\text { al. }(2011)\end{array}$ & Length-fast chalcedony from an agate geode. & $670 \pm 10$ & 0.31 & 0.56 \\
\hline
\end{tabular}

compositions. Data were included only if they (1) were measured for silica rocks, (2) did not undergo smoothing or any other form of processing (i.e., only crude data were considered), and (3) were determined over a sufficiently wide range with at least four measuring points. The screened data were then further compared and analyzed. One has to keep in mind that it is very challenging to compare results from various sources obtained by quite different measuring methods and often of unknown accuracy (Seipold, 1998).

\subsection{METHODS}

Under high temperature, the water content in rocks is significantly reduced due to a series of physical and chemical reactions (Heuze, 1983; Nasseri et al., 2007; Zhang et al., 2015; Sun et al., 2016). Near infrared spectroscopy (NIR) allows quantifying the content of water related to transformations in rocks during heating. For instance, the NIR absorption spectrum of chalcedony shows a combination band at about $5200 \mathrm{~cm}^{-1}$ that can be attributed to the $\mathrm{OH}$ stretching/HOH bending combination mode of molecular water and another combination band at 
about $4500 \mathrm{~cm}^{-1}$ that can be attributed to the $\mathrm{OH}$ stretching/SiOH bending combination mode of silanole (Aines et al., 1984; Schmidt et al., 2011). For NIR, the sample has to be thin enough for signals to show up in the spectrum and thick enough for the $\mathrm{SiOH}$ combination band to be well identifiable. The ideal thickness is reported to be $0.5-4 \mathrm{~mm}$ through experimentation (Schmidt et al., 2011). For sample preparation, the rocks with various initial water content and mineral compositions are cut into slabs before the NIR analysis (the thickness of the exact samples are summarized in Table 1). The rock samples are then heated to preset temperature in an electrical furnace (Schmidt et al., 2011; Schmidt et al., 2012a) for the thermal evolution of different $\mathrm{OH}$ species to take place. The expected transformations are basically completed after thermal treatment at target temperature for $50 \mathrm{~min}$. To ensure completion, the samples are kept at given temperature for $2.5 \mathrm{~h}$ (Fukuda and Nakashima, 2008; Schmidt et al., $2012 b)$. The heating rates are carefully selected to prevent thermal fracturing, cracking, or crazing (Schmidt et al., 2011; Schmidt et al., 2012a; Schmidt et al., 2012b).

In addition to NIR, Raman spectroscopy and thermo gravimetric analysis (TGA) are also used to evaluate the thermal transformations of some silica rocks. For instance, in the Raman spectrum of chalcedony, the band at $501 \mathrm{~cm}^{-1}$ that can be attributed to moganite has been used to evaluate the quartz/moganite ratio in silica rocks (Kingma and Hemley, 1994; Heaney et al., 2007). Figure 1 shows the Raman spectrum of the flint sample GP-S-01, which contains entirely LF-chalcedony, before and after annealing. It can be seen that after annealing at $700{ }^{\circ} \mathrm{C}$ for $6 \mathrm{~h}$, the Raman band at $503 \mathrm{~cm}^{-1}$ has disappeared almost completely. This is because of the decreased $\mathrm{SiOH}$ (silanole) content in the sample after heating (Schmidt et al., 2012a), rather than the variation of moganite content. The mass loss of the silica rocks during high temperature can also be measured by thermo gravimetric analysis (TGA), which is used to analyze specific physical properties. The major transformations of silica rocks after annealing at high temperature can be clearly noted by looking at the IR spectra and the TGA curves.

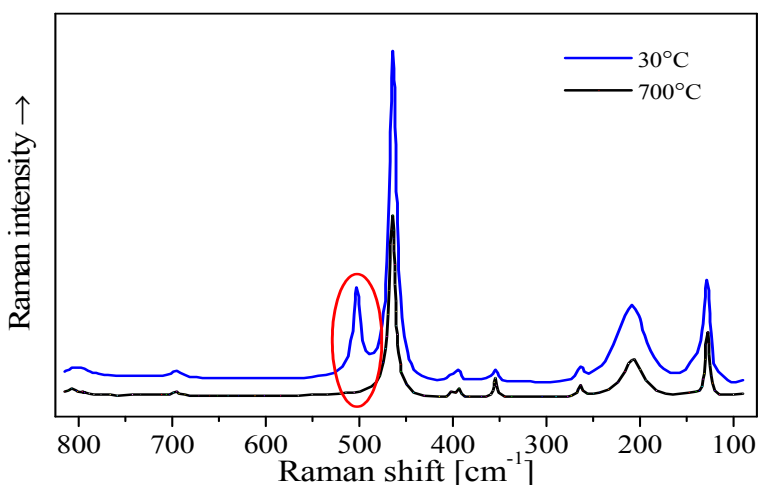

Fig. 1 The Raman spectra of flint samples before and after annealing at $700{ }^{\circ} \mathrm{C}$ (data from Schmidt et al., 2012a).

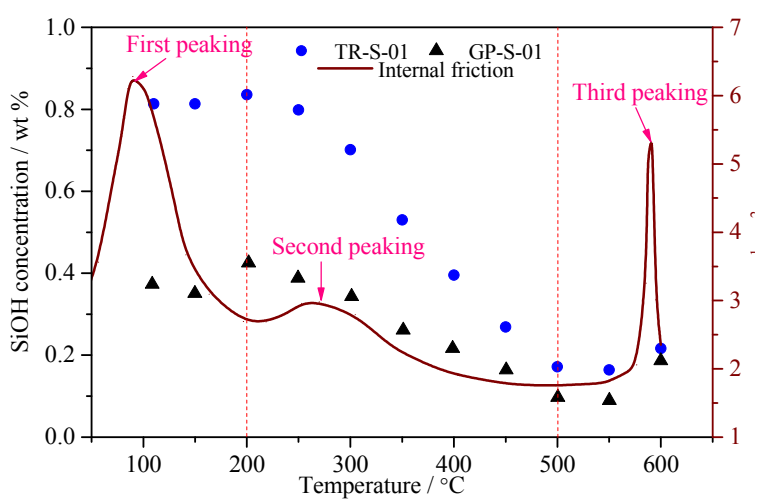

(a)

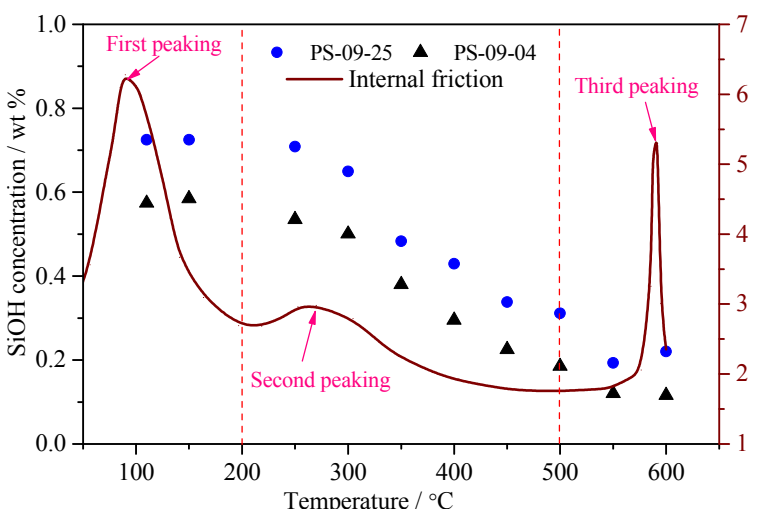

(b)

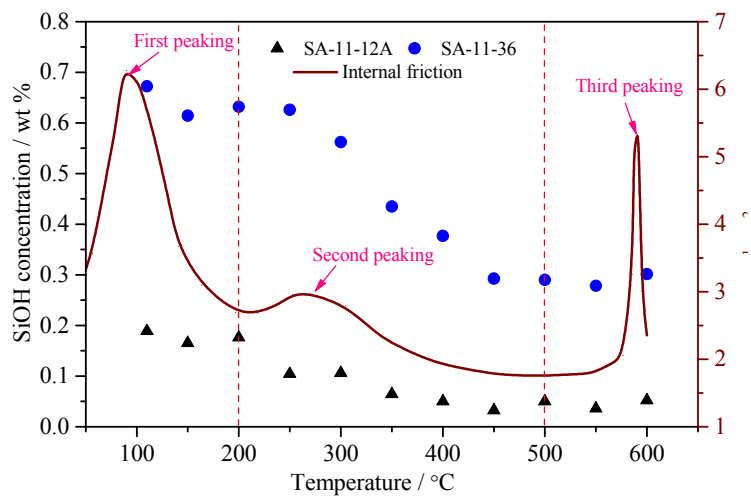

(c)

Fig. 2 The influence of annealing temperature on the content of silanole in silica rocks (data from Schmidt et al., 2011; Schmidt et al., 2012b; Schmidt et al., 2013b).

\section{ANALYSIS}

\subsection{VARIATION OF SIOH UPON HEAT TREATMENT}

Figure 2 plots the $\mathrm{SiOH}$ content in rock (determined from NIR) as a function of annealing temperature and illustrates that the $\mathrm{SiOH}$ (silanole) content in rock generally decreases along with heat treatment. Figure 2(a) clearly shows three distinct temperature ranges associated with the variation of $\mathrm{SiOH}$, i.e., (1) $110-250{ }^{\circ} \mathrm{C}$, (2) $250-550{ }^{\circ} \mathrm{C}$, and (3) $>550{ }^{\circ} \mathrm{C}$. When the temperature is below $250{ }^{\circ} \mathrm{C}$, the $\mathrm{SiOH}$ content changes very little (e.g., TR-S-01, from $0.81 \mathrm{wt} \%$ before annealing to $0.8 \mathrm{wt} \%$ at $250{ }^{\circ} \mathrm{C}$; GP$\mathrm{S}-01$, from $0.38 \mathrm{wt} \%$ before annealing to $0.4 \mathrm{wt} \%$ at $250{ }^{\circ} \mathrm{C}$; PS-09-04, from $0.58 \mathrm{wt} \%$ before annealing to $0.54 \mathrm{wt} \%$ at $250{ }^{\circ} \mathrm{C}$; PS- $09-25$, from $0.72 \mathrm{wt} \%$ before 
annealing to $0.7 \mathrm{wt} \%$ at $250{ }^{\circ} \mathrm{C}$; SA-11-12A, from $0.19 \mathrm{wt} \%$ before annealing to $0.11 \mathrm{wt} \%$ at $250{ }^{\circ} \mathrm{C}$; SA$11-36$, from $0.86 \mathrm{wt} \%$ before annealing to $0.63 \mathrm{wt} \%$ at $250{ }^{\circ} \mathrm{C}$ ). Most of the $\mathrm{SiOH}$ is lost as the temperature rises from $250{ }^{\circ} \mathrm{C}$ to $550{ }^{\circ} \mathrm{C}$, and the $\mathrm{SiOH}$ content reaches a minimum at about $550{ }^{\circ} \mathrm{C}$. Afterwards, the $\mathrm{SiOH}$ content recovers slowly until it arrives at an approximately constant value. Note that $\mathrm{SiOH}$ still exists at as high as $600{ }^{\circ} \mathrm{C}$ even though its content is small. The internal friction of rock is related to the interface, the point defects, and the water in the pores (Xi, 1994; Tan et al., 1995). The internal friction peaking (mainly second peaking) of silica rocks could be considered as the reaction between $\mathrm{SiOH}$ to form $\mathrm{H}_{2} \mathrm{O}$.

\subsection{VARIATION OF $\mathrm{H}_{2} \mathrm{O}$ UPON HEAT TREATMENT}

The content of molecular water is quantified based on the smoothed transmission spectra according to the molar absorption coefficients given by Scholze (1960). The $\mathrm{H}_{2} \mathrm{O}$ held loosely in the open pores of rocks is measured by subtracting the absorption band of $\mathrm{H}_{2} \mathrm{O}$ at $5220 \mathrm{~cm}^{-1}$ in the spectrum of dehydrated rock from the same absorption band in the spectrum of the hydrated rock. The resulting value then corresponds to the water residing in the open pores of the rock (Schmidt et al., 2011). Figure 3 plots the content of water in the open pores of selected rock samples and shows that in general the water content decreases with rising temperature. The decline of pore water content is most significant at $200-300{ }^{\circ} \mathrm{C}$. When the temperature rises above $300{ }^{\circ} \mathrm{C}$, the rate of water loss slows down, and the water content may even rebound slightly. The silica rocks lose most of its open pores at $200-300{ }^{\circ} \mathrm{C}$ (sample VC-12-01, 93\%; sample VC-12-02, 90 \%; sample PS-09-04, $68 \%$; sample PS-09-25, 56 \%; sample TR-S-01, 78\%; sample GP-S-01, 91\%).

The $\mathrm{H}_{2} \mathrm{O}$ content of the dehydrated rocks is determined by the combination band at $5220 \mathrm{~cm}^{-1}$ in the NIR. The water strongly retained in the closed pores or interstices of the rocks cannot be easily evacuated and gives the absorbance signal at 5220 $\mathrm{cm}^{-1}$ in the NIR (Schmidt et al., 2011; Schmidt et al., 2012a). Figure 4 illustrates the variation of the strongly retained water in silica rocks as a function of annealing temperature, and the patterns are inconsistent across different rock samples. Figure 4(a) shows that the rock samples SP-09-41, SB-Cal-06, and SB-Cal-07 lose a small amount of water at 110$300{ }^{\circ} \mathrm{C}$ and then rapidly dehydrate from $300{ }^{\circ} \mathrm{C}$ onwards, eventually losing almost all water at $\sim 600{ }^{\circ} \mathrm{C}$. Figure 4(b) shows that for the rock samples TR-S-01 and PS-09-13, the water content firstly increases at $250-500^{\circ} \mathrm{C}$ and then decreases at $>500{ }^{\circ} \mathrm{C}$. Figure 4 (c) shows that the rock samples GPS-01 and PS-09-14 have rising water content over the entire temperature range. These differences may be attributed to the internal micro cracks and pores that differ greatly across various silica rocks.

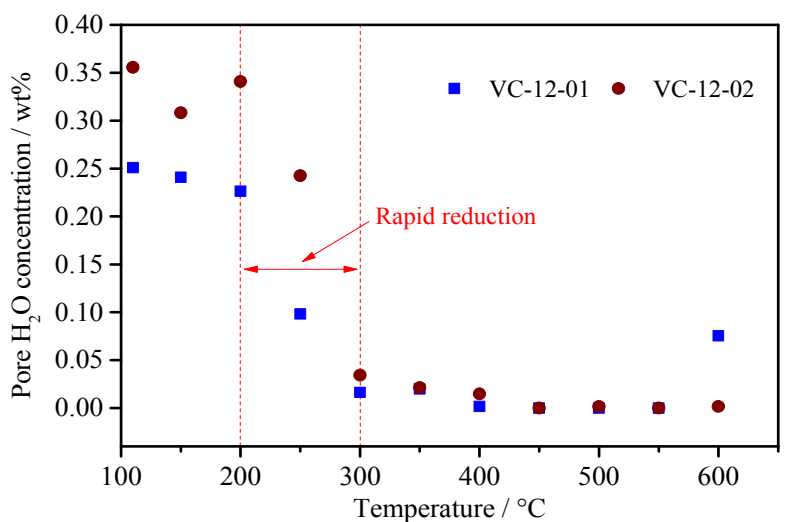

(a)

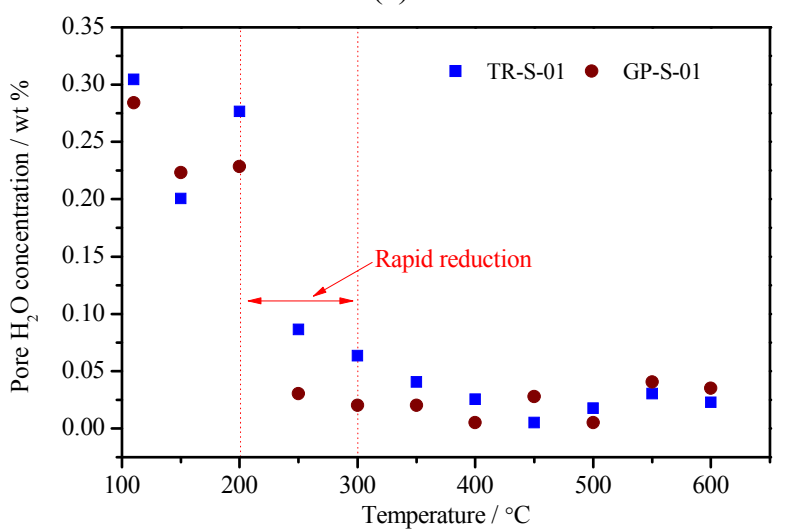

(b)

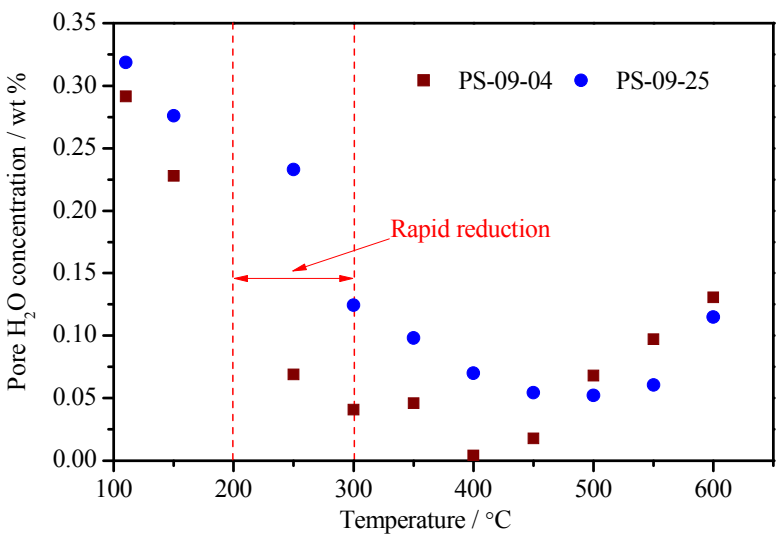

(c)

Fig. 3 The influence of annealing temperature on the content of molecular water held in the open pores of rocks (data from Schmidt et al., 2011; Schmidt et al., 2012b; Schmidt et al., 2013b).

\section{DISCUSSION}

\subsection{COMBINATION OF RAMAN SPECTRA AND TGA ANALYSIS}

The variation of the $\mathrm{SiOH}$ (silanole) groups can be analyzed by both NIR (Schmidt et al., 2012b) and Raman spectroscopy (Kingma and Hemley, 1994; Götze et al., 1998; Rodgers and Gressey, 2001; Heaney et al., 2007). Figure 5 shows the spectral parameters of the rock sample PS-09-04, including the NIR absorption of $\mathrm{SiOH}$ at $4547 \mathrm{~cm}^{-1}$ and the relative intensity of the Raman band at $503 \mathrm{~cm}^{-1}$, as a function 


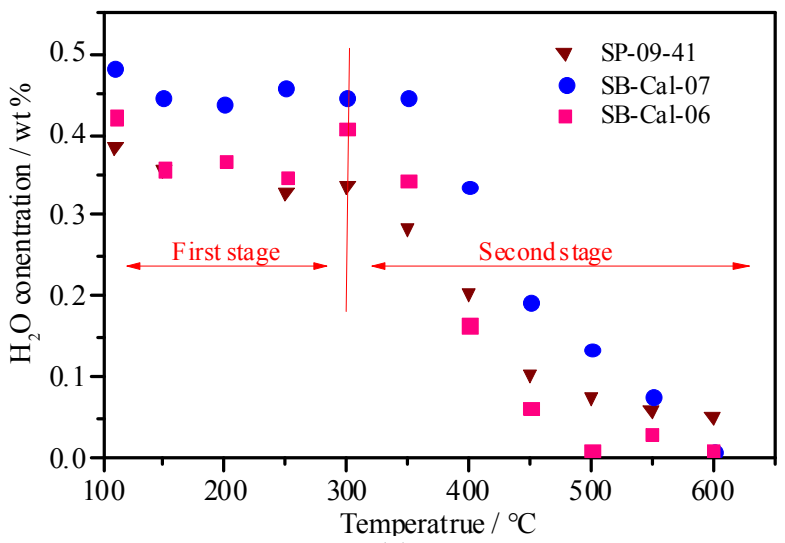

(a)

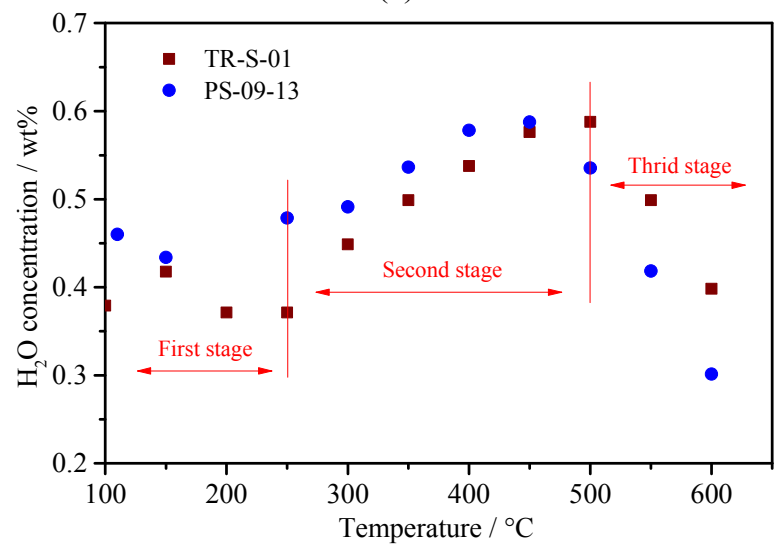

(b)

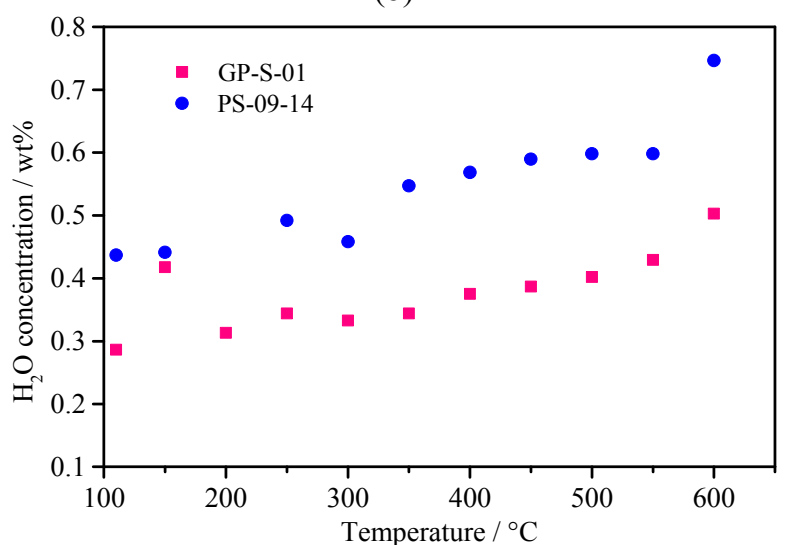

(c)

Fig. 4 The content of molecular water strongly retained in the rock structure (data from Schmidt et al., 2011; Schmidt et al., 2012b; Schmidt et al., 2013b).

of annealing temperature. The same polished section of the sample PS-09-04 is selected for the NIR and the Raman measurements. It can be seen from Figure 5 that the NIR absorbance and the relative Raman intensity have similar patterns, i.e., both remain relatively stable at $<300{ }^{\circ} \mathrm{C}$ and readily decline as the temperature rises above $300{ }^{\circ} \mathrm{C}$.

Figure 6 shows the relative intensity of the Raman band at $503 \mathrm{~cm}^{-1}$ and the TGA mass loss of the sample PS-09-04 at $450{ }^{\circ} \mathrm{C}$ as a function of time. Both the Raman and the TGA curves show a sharp decline in first $60 \mathrm{~min}$ at $450{ }^{\circ} \mathrm{C}$ and change relatively little from then on. The good correlation between the Raman band at $503 \mathrm{~cm}^{-1}$ and the mass loss of silica rock indicates that the mass loss can be well associated with the changes of the $\mathrm{SiOH}$ in the silica sample.

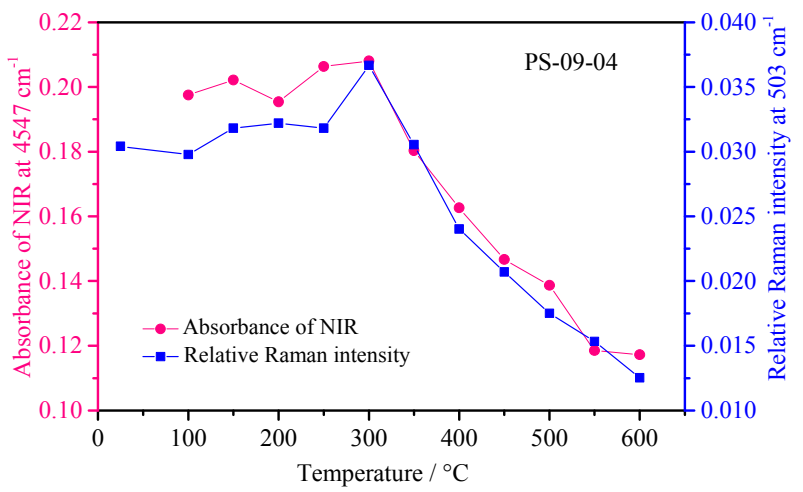

Fig. 5 The absorbance of the NIR band at $4547 \mathrm{~cm}^{-1}$ and the relative intensity of the Raman band at $503 \mathrm{~cm}^{-1}$ of the rock sample PS-09-04 at rising temperature (data from Schmidt et al., 2012a).

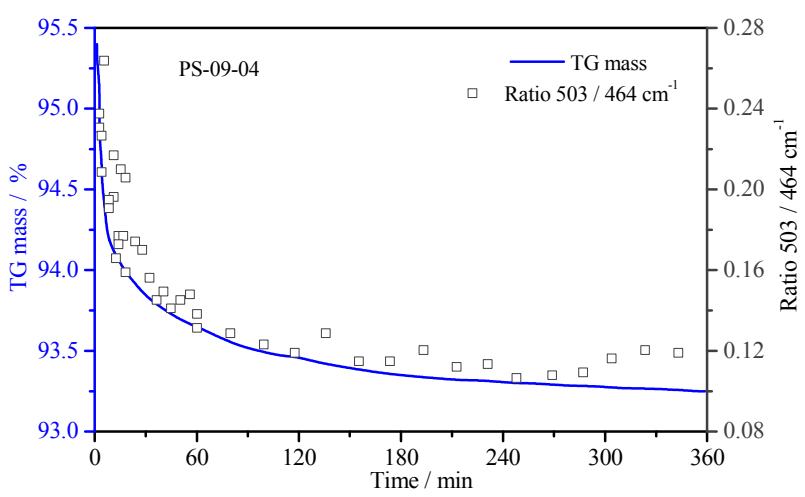

Fig. 6 The Raman band at $503 \mathrm{~cm}^{-1}$ and the TGA mass loss of the rock sample PS-09-04 at $450{ }^{\circ} \mathrm{C}$ as a function of time (data from Schmidt et al., 2012a).

\subsection{TEMPERATURE-INDUCED TRANSFORMATIONS OF SILICA ROCKS}

Rocks experience a series of physical and chemical changes under high temperature, including loss of water, change of mass and volume, and change of composition. The surveyed silica rock samples differ in their $\mathrm{SiOH}$ and water contents, and their temperature-induced transformations are analyzed as follows. From the derivative TGA curves of three flint samples in Figure 7, the major episodes and the key temperature-induced transformations of silica rocks can be deduced as follows.

The first mass loss, which occurs at $<150{ }^{\circ} \mathrm{C}$, can be attributed to the evaporation of molecular water held between the grains and adsorbed on the surface. When the annealing temperature rises to $250-300{ }^{\circ} \mathrm{C}$, 


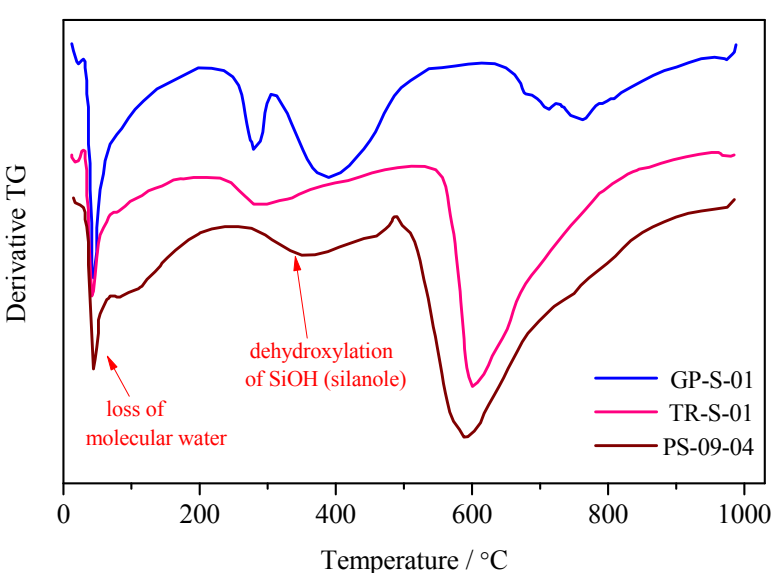

Fig. 7 The derivative TGA curves (at $1{ }^{\circ} \mathrm{C} / \mathrm{min}$ heating rate) of three silica rocks (data from Schmidt et al., 2012b).

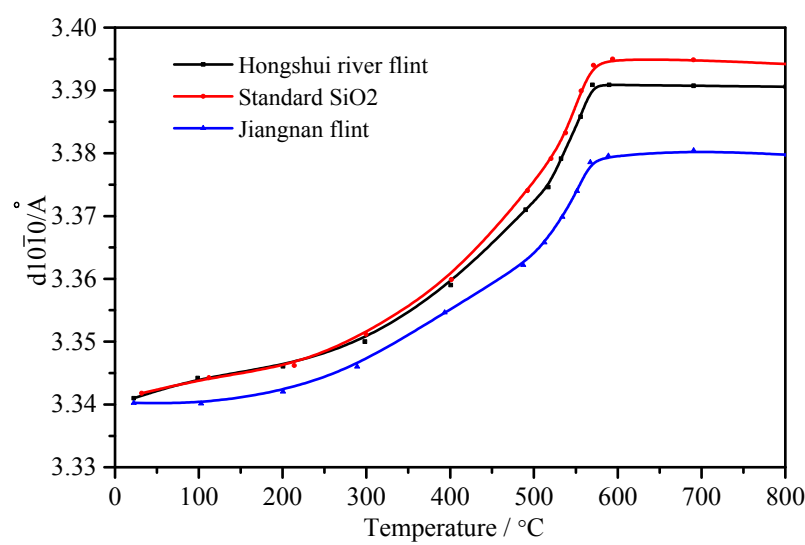

Fig. 8 The interplanar spacing $\left(d_{10 \overline{1} 0}\right)$ of three flint samples as a function of temperature (data from $\mathrm{Fu}$ and $\mathrm{Xu}, 1992$ ).

the reaction between $\mathrm{SiOH}$ (see Equation 1) takes place and creates new $\mathrm{Si}-\mathrm{O}-\mathrm{Si}$ bonds, and the hardness of the rocks increases accordingly. However, most of the molecular water created by this reaction could escape through a relatively large network of open pores in silcrete compared to flint (Flörke et al., 1982; Graetsch et al., 1985; Schmidt et al., 2011; Schmidt et al., 2012b).

$$
\mathrm{Si}-\mathrm{OH}+\mathrm{HO}-\mathrm{Si} \rightarrow \mathrm{Si}-\mathrm{O}-\mathrm{Si}+\mathrm{H}_{2} \mathrm{O}
$$

When the temperature reaches $400-500{ }^{\circ} \mathrm{C}$, almost all open pores in the rocks are closed. The decrease of the pore volume is not related to the formation of new $\mathrm{Si}-\mathrm{O}-\mathrm{Si}$ bonds because there is little mass loss (Figure 7). As the temperature rises to $\sim 600^{\circ} \mathrm{C}$, a rapid thermal volume expansion takes place and contributes to the fracturing of rocks. Wadley and Prinsloo (2014) have demonstrated that this increase of volume can reach up to $2 \%-4 \%$. According to the variation of interplanar spacings of two different flints and standard quartz (Figure 8), the

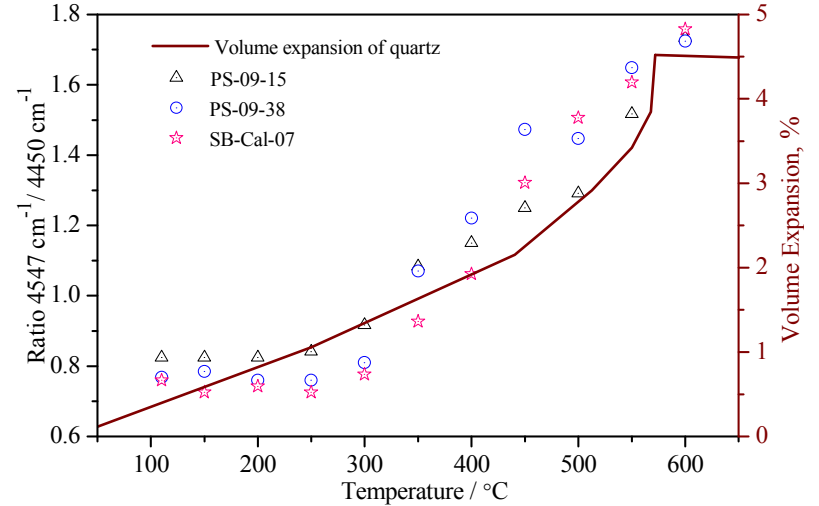

(a)

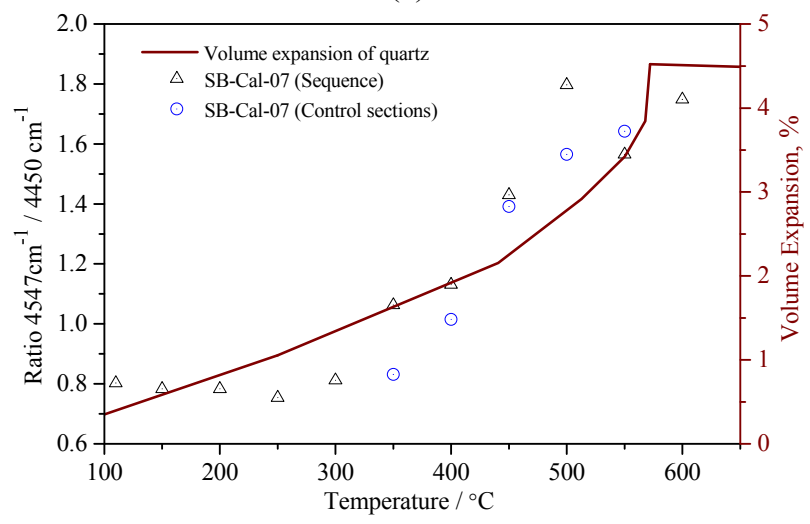

(b)

Fig. 9 Volume expansion and the ratio of NIR absorbance at $4547 \mathrm{~cm}^{-1}$ to NIR absorbance at $4450 \mathrm{~cm}^{-1}$ (data from Schmidt et al., 2011).

increased volume of flints is caused by the phase transition of its internal quartz. The increase of volume generates micro pores or cracks within the rocks and allows the absorption of molecular water, which is why the water content in the pores no longer decreases at temperatures higher than $550{ }^{\circ} \mathrm{C}$ (Figure 3).

Figure 9 plots against temperature the volume expansion of quartz as well as the ratio of the NIR absorbance at $4450 \mathrm{~cm}^{-1}$ to the NIR absorbance at $4547 \mathrm{~cm}^{-1}$. This ratio is a measure of the shape of the combination band of the hydrated rock and therefore the involvement of $\mathrm{SiOH}$ in hydrogen bonding (Schmidt et al., 2011). Figure 9 shows that this ratio appears to correlate very well with the volume expansion of rocks at high temperature.

\section{CONCLUSIONS}

This paper analyzes the transformation of silica rocks under high temperature by reviewing data reported in earlier works. Researchers have previously made use of near infrared spectroscopy (NIR), thermo gravimetric analysis (TGA), and Raman spectroscopy, all of which help to examine the transformations of silica rocks. The major transformations of the silica rocks under high temperature can be summarized as 
follows. Water adsorbed in the pores of silica rocks is firstly lost at $<150{ }^{\circ} \mathrm{C}$ upon heating. When the temperature arrives at $250-300{ }^{\circ} \mathrm{C}$, the reaction between $\mathrm{SiOH}$ produces molecular water at the defect sites and twin boundaries within the quartz crystallites of the rocks, and this reaction proceeds further at 300 $400{ }^{\circ} \mathrm{C}$. When the temperature rises to $550-600{ }^{\circ} \mathrm{C}$, the volume of the quartz particles expands, which contributes to the fracturing of rocks and allows the water newly generated from the reaction of $\mathrm{SiOH}$ to evacuate from the rocks. Note that it is challenging to analyze the transformations of the rocks with similar properties (i.e., structure and mineral composition), and a variety of complementary methods should be considered in combination.

\section{ACKNOWLEDGMENTS}

This research was supported by "the Fundamental Research Funds for the Central Universities" (No. 2017XKQY024) and the Priority Academic Program Development of Jiangsu Higher Education Institutions.

\section{REFERENCES}

Abdulagatov, I.M., Abdulagatova, Z.Z., Kallaev, S.N., Bakmaev, A.G. and Ranjith, P.G.: 2015, Thermaldiffusivity and heat-capacity measurements of sandstone at high temperatures using laser flash and DSC methods. Int. J. Thermophys., 36, 658-691. DOI: $10.1007 / \mathrm{s} 10765-014-1829-4$

Aines, R.D., Kirby, S.H. and Rossman, G.R.: 1984, Hydrogen speciation in synthetic quartz. Phys. Chem. Minerals, 11, 5, 204-212. DOI: 10.1007/BF00308135

Brown, K.S., Marean, C.W., Herries, A.I.R., Jacobs, Z., Tribolo, C., Braun, D., Roberts, D.L., Meyer, M.C. and Bernatchez, J.: 2009, Fire as an engineering tool of early modern humans. Science, 325, 859-862. DOI: $10.1126 /$ science. 1175028

Domanski, M. and Webb, J.A.: 1992, Effect of heat treatment on siliceous rocks used in prehistoric lithic technology. J. Archaeol. Sci., 19, 6, 601-614. DOI: 10.1016/0305-4403(92)90031-W

Flörke, O.W., Köhler-Herbertz, B., Langer, K. and Tönges, I.: 1982, Water in microcrystalline quartz of volcanic origin: agates. Contrib. Mineral. Petr., 80, 4, 324-333. DOI: $10.1007 / \mathrm{BF} 00378005$

Fridleifsson, I.B.: 2001, Geothermal energy for the benefit of the people. Renew. Sust. Energ. Rev., 5, 3, 299 312. DOI: $10.1016 / \mathrm{S} 1364-0321(01) 00002-8$

Fu, G. and Xu, H.: 1992, A study on $\alpha$-quartz $\rightleftharpoons \beta$-quartz phase transition of two kinds of cherts. Chin. J. Geol., 1, 50-54, (in Chinese).

Fukuda, J. and Nakashima, S.: 2008, Water at high temperatures in a microcrystalline silica (chalcedony) by in-situ infrared specroscopy: physicochemical states and dehydration behavior. J. Miner. Petrol. Sci., 103, 112-115. DOI: 10.2465/jmps.071022a

Götze, J., Nasdala, L., Kleeberg, R. and Wenzel, M.: 1998, Occurrence and distribution of "moganite" in agate/chalcedony: a combined micro-Raman, Rietveld, and cathodoluminescence study. Contrib. Mineral. Petrol., 133, 1, 96-105. DOI: $10.1007 / \mathrm{s} 004100050440$
Graetsch, H., Flörke, O.W. and Miehe, G.: 1985, The nature of water in chalcedony and Opal-C from Brazilian agate geodes. Phys. Chem. Minerals, 12, 5, 300-306. DOI: $10.1007 / \mathrm{BF} 00310343$

Heaney, P.J., Mckeown, D.A. and Post, J.E.: 2007, Anomalous behavior at the I2/a to Imab phase transition in $\mathrm{SiO}_{2}$-moganite: An analysis using hardmode Raman spectroscopy. Am. Mineral., 92, 631639. DOI: $10.2138 / \mathrm{am} .2007 .2184$

Heuze, F.E.: 1983, High-temperature mechanical, physical and thermal properties of granitic rocks - A review. Int. J. Rock Mech. Min. Sci. Geomech. Abstr., 20, 1, 3-10. DOI: 10.1016/0148-9062(83)91609-1

Höfer, M. and Schilling, F.R.: 2002, Heat transfer in quartz, orthoclase, and sanidine at elevated temperature. Phys. Chem. Minerals, 29, 571-584.

DOI: $10.1007 / \mathrm{s} 00269-002-0277-\mathrm{z}$

Hofmeister, A.M.: 2014, Thermal diffusivity and thermal conductivity of single-crystal $\mathrm{MgO}$ and $\mathrm{Al}_{2} \mathrm{O}_{3}$ and related compounds as a function of temperature. Phys. Chem. Minerals, 41, 361-371. DOI: $10.1007 / \mathrm{s} 00269-014-0655-3$

Kingma, K.J. and Hemley, R.J.: 1994, Raman spectroscopic study of microcrystalline silica. Am. Mineral., 79, 269-273.

Kovačević, M.S., Bačić, M. and Arapov, I.: 2013, Possibilities of underground engineering for the use of shallow geothermal energy. Gradevinar., 64, 10191028 .

Léa, V.: 2005, Raw, pre-heated or ready to use: Discovering specialist supply systems for flint industries in midNeolithic (Chassey culture) communities in southern France. Antiquity, 79, 1-15.

DOI: $10.1017 /$ S0003598X00113699

Mercieca, A. and Hiscock, P.: 2008, Experimental insights into alternative strategies of lithic heat treatment. J. Archaeol. Sci., 35, 9, 2634-2639. DOI: 10.1016/j.jas.2008.04.021

Mourre, V., Villa, P. and Henshilwood, C.S.: 2010, Early use of pressure flaking on lithic artifacts at Blombos Cave, South Africa. Science, 330, 659-662. DOI: $10.1126 /$ science. 1195550

Nasseri, M.H.B., Schubnel, A. and Young, R.P.: 2007, Coupled evolutions of fracture toughness and elastic wave velocities at high crack density in thermally treated westerly granite. Int. J. Rock Mech. Min. Sci., 44, 601-616. DOI: 10.1016/j.ijrmms.2006.09.008

Post, J.L. and Noble, P.N.: 1993, The near-infrared combination band frequencies of dioctahedral smectites, micas, and illites. Clay. Clay Miner., 41, 6, 639-644. DOI: 10.1346/CCMN.1993.0410601

Ríos, S., Salje, E.K.H. and Redfern, S.A.T.: 2001, Nanoquartz vs. macroquartz: a study of the $\alpha \leftrightarrow \beta$ phase transition. Eur. Phys. J. B, 20, 75-83.

Rodgers, K.A. and Cressey, G.: 2001, The occurrence, detection and significance of moganite $\left(\mathrm{SiO}_{2}\right)$ among some silica sinters. Mineral. Mag., 65, 2, 157-167. DOI: $10.1180 / 002646101550181$

Schindler, D.L., Hatch, J.W., Hay, C.A. and Bradt, R.C.: 1982, Aboriginal thermal alteration of a Central Pennsylvania Jasper: Analytical and behavioral implications. Am. Antiquity, 47, 3, 526-544. DOI: $10.2307 / 280233$

Schmidt, P., Badou, A. and Fröhlich, F.: 2011, Detailed FT near-infrared study of the behaviour of water and hydroxyl in sedimentary length-fast chalcedony, $\mathrm{SiO}_{2}$, 
upon heat treatment. Spectrochimica Acta Part A, 81, 552-559. DOI: 10.1016/j.saa.2011.06.050

Schmidt, P., Bellotgurlet, L., Slodczyk, A. and Fröhlich, F.: 2012a, A hitherto unrecognised band in the Raman spectra of silica rocks: Influence of hydroxylated $\mathrm{Si}-\mathrm{O}$ bonds (silanole) on the Raman moganite band in chalcedony and flint $\left(\mathrm{SiO}_{2}\right)$. Phys. Chem. Minerals, 39, 6, 455-464. DOI: 10.1007/s00269-012-0499-7

Schmidt, P., Léa, V., Sciau, P. and Fröhlich, F.: 2013a, Detecting and quantifying heat treatment of flint and other silica rocks: A new non-destructive method applied to heat-treated flint from the neolithic chassey culture, Southern France. Archaeometry, 55, 5, 794805. DOI: $10.1111 /$ j.1475-4754.2012.00712.x

Schmidt, P., Masse, S., Laurent, G., Slodczyk, A., Bourhis, E.L., Perrenoud, C., Livage, J. and Fröhlich, F.: $2012 b$, Crystallographic and structural transformations of sedimentary chalcedony in flint upon heat treatment. J. Archaeol. Sci., 39, 1, 135-144. DOI: 10.1016/j.jas.2011.09.012

Schmidt, P., Porraz, G., Slodczyk, A., Bellot-gurlet, L., Archer, W. and Miller, C.E.: 2013b, Heat treatment in the South African Middle Stone Age: temperature induced transformations of silcrete and their technological implications. J. Archaeol. Sci., 40, 9, 3519-3531. DOI: 10.1016/j.jas.2012.10.016

Seipold, U.: 1998, Temperature dependence of thermal transport properties of crystalline rocks-a general law. Tectonophysics, 291, 161-171. DOI: $10.1016 / \mathrm{S} 0040-1951(98) 00037-7$

Sun, Q., Lü, C., Cao, L., Li, W., Geng, J. and Zhang, W.: 2016, Thermal properties of sandstone after treatment at high temperature. Int. J. Rock Mech. Min., 85, 6066. DOI: 10.1016/j.ijrmms.2016.03.006

Tan, Q., Xi, D., Zhou, G. and Ma, Y.: 1995, Low frequency internal friction study on granites. J. China Univ. Sci. Technol., 25, 3, 368-372, (in Chinese).
Tiffagom, M.: 1998, Témoignages d'un traitement thermique des feuilles de laurier dans le Solutréen supérieur de la grotte du Parpalló (Gandia, Espagne). Paléo, 10, 147-161. DOI: 10.3406/pal.1998.1134

Verma, A.K., Jha, M.K., Maheshwar, S., Singh, T.N. and Bajpai, R.K.: 2016, Temperature-dependent thermophysical properties of Ganurgarh shales from Bhander group, India. Environ. Earth Sci., 75, 300. DOI: $10.1007 / \mathrm{s} 12665-015-4992-4 \mathrm{a}$

Wadley, L. and Prinsloo, L.C.: 2014, Experimental heat treatment of silcrete implies analogical reasoning in the Middle Stone Age. J. Hum. Evol., 70, 5, 49-60. DOI: 10.1016/j.jhevol.2013.11.003

Wang, M., Li, X. and Dai, X.: 2016, Thermal evolution characteristics of Triassic coal in Chuxiong Basin and its geological significance. Int. J. Min. Sci. Technol., 26, 5, 937-945. DOI: 10.1016/j.ijmst.2016.05.035

Xi, D.: 1994, Physical characteristics of mineral phase transition in the granite. Acta Mineral. Sinica, 14, 3, 223-227, (in Chinese).

Xiao, C., Wei, C., Guo, L. and Shen, J.: 2016, Effect of temperature and stress on molecular structure and carbon monoxide generation of lignite from Kailuan mining area. Int. J. Min. Sci. Technol., 26, 3, 437-441. DOI: 10.1016/j.ijmst.2016.02.011

Zhang, W., Qian, H., Sun, Q. and Chen, Y.: 2015, Experimental study of the effect of high temperature on primary wave velocity and microstructure of limestone. Environ. Earth Sci., 74, 5739-5748. DOI: $10.1007 / \mathrm{s} 12665-015-4591-4$ 